\title{
THE 10TH FLORA MALESIANA SYMPOSIUM
}

The 10th Flora Malesiana Symposium was held at the Royal Botanic Garden Edinburgh (RBGE) between 11 and 15 July 2016 and was attended by 185 researchers from 25 countries. Over five days, taxonomists, horticulturists and conservationists came together to present and discuss their research on the plant diversity of the Malesian region. Over 160 presentations were given and a series of very popular workshops was run.

The theme of the symposium was Classify, Cultivate, Conserve. At the heart of Flora Malesiana and its symposia is the taxonomic research which underpins all plant diversity activity. During this 10th symposium we took the opportunity to highlight and celebrate the role horticulture plays in helping us to understand and maintain this diversity and to explore ways to link the taxonomic community more closely to the conservation community so that our joint endeavours have greater impact.

The conference started with a video presentation by Dr Braulio Dias, the Executive Secretary of the Convention on Biological Diversity, in which he emphasised his support for the Flora Malesiana project and the work of the Flora Malesiana community in researching one of the richest and least known floras in the world. In his presentation he acknowledged that the description and classification of plant species and the assessment of their conservation status are the preconditions for prioritising conservation actions. Taking the opportunity to highlight the fact that ecosystem restoration is increasingly gaining momentum in many countries, he encouraged Flora Malesiana institutions to join the Ecological Restoration Alliance of Botanic Gardens. He also emphasised the need for the inclusion of indigenous communities, local communities and the private sector when managing natural and near-natural ecosystems. In finishing, he highlighted the role of Flora Malesiana scientists as ambassadors who can bridge the gap between modern scientific knowledge and indigenous and local knowledge systems, and who, by helping us to understand the flora of the region better, also facilitate finding a future where we may live in harmony with nature.

Over the week we had an impressive range of keynote speakers who inspired us to redouble our efforts in the many and varied activities we undertake in order to understand and conserve the flora of Malesia. Peter Ashton warned us not to become complacent about the many things already achieved by the Flora Malesiana community and to focus more on conservation assessment, questioning what future biodiversity science and the indigenous flora have if we can't conserve at least some of the ecosystems in which they occur. He talked about the important role systematists have in recording precise habitat information, pointing out that in doing so they can provide the data essential in planning priorities for conservation. In finishing, he noted that it is plant scientists who are primarily responsible for guiding the conservation planner with advice arising from the knowledge gained from their observations.

Tony Whitten gave a heartfelt account of the trees he had loved and (almost) lost, but it was the first half of his talk, focusing on the new generation of researchers in the 
audience and the career choices ahead of them that, given his premature death 16 months later, was perhaps the most moving. Reminiscing about flying over the large expanses of forest of Kalimantan and Sumatra in his early career and comparing this with today, when only small fragments of forest are left, he wished he had been able to do more to pass these forests on to the next generation. However, he still encouraged the younger members of the audience to think big and develop new bold visions, pointing out that it was the optimism of young people within that conservation community that had driven him to continue with his endeavours. One real success story in SE Asia achieved over his lifetime that he was keen to highlight was the massive improvement in the pool of human resources from within the region, so that today countries are delivering research and conservation actions for themselves. Addressing the systematic community, he urged researchers to look at more than just their own research needs and to incorporate the context in which they are working into their professional lives. He emphasised the value of keeping an interest in areas where you have worked, as problems are rarely solved in three or five years, and not to assume that someone else will pick up your research conclusions and put them into policy and actions, suggesting that in many cases you are probably the best person to deliver them.

George Argent provided a beautiful visual tour of the plants he had brought into cultivation from across Malesia. Underlining the fact that these had been collected primarily for scientific purposes, in particular to facilitate the naming and description of species, he emphasised that much of his research success had been dependent on the expertise of horticultural staff to grow these plants in cultivation. Several examples were given of species collected sterile in the field that, when brought back to RBGE and grown on to flower, turned out to be species new to science. He also explained to the audience how species in cultivation had helped alter his taxonomic view of some species, allowed pollination biology observations, facilitated cytological studies and provided an insight into plant development. Unfortunately many of the plants he had brought into cultivation are now recorded as threatened in the wild due to their natural habitat being severely degraded and as such the collection is now of conservation importance. In this context he stressed the importance of repatriation of material to the country of origin when suitable conditions for cultivation are available. In finishing, he described how living material is used to illustrate species in amazing detail and to engage the public with the astonishing plant diversity of Malesia.

Sara Oldfield, focusing her talk on scaling up action in plant conservation, asked why we are not more effective, considering that we have a global framework and wide public support for plant conservation. One suggestion she put forward was that we are often not in a position to answer some of the basic questions that would allow us to make convincing arguments to scale up our activities, questions such as: how many plant species are there? Which species are threatened? What are the priority areas for conservation? How do we effectively conserve and utilise species? The Global Strategy for Plant Conservation (GSPC) is trying to focus efforts on answering these questions, and Sara emphasised the immense importance of the Malesian region to plant conservation and 
the role of the Flora Malesiana community in collating existing information and making it available to others to scale up conservation action. She praised botanic gardens as champions of plant conservation, noting that Malesia has 33 botanic gardens at present. This number is set to double with the Indonesian regional botanic garden initiative so there is a great opportunity to help increase plant conservation activities significantly in the region and to develop new networks and partnerships with other sectors.

Joeni Setijo Rahajoe gave an enlightening talk on the 175-year history of Herbarium Bogoriense, highlighting its important links to the Flora Malesiana project and its role in delivering an enumeration of the Indonesian flora. A major component of the activities of the herbarium are botanical exploration, species discovery and building taxonomic capacity in Indonesia. She referred to the publication of the present status of biodiversity in Indonesia, which was produced with support from the Indonesian National Planning Agency and Ministry of Environment and Forestry, and noted that this forms part of the Indonesian biodiversity strategy and action plan. A key part of this strategy will be to database the national collection. To date, about half of the 900,000 specimens held in the herbarium have been entered into the institutional database and this is due to be completed within the next five years. LIPI has the role of managing this biodiversity data and has developed the Indonesian biodiversity information facility to support the Indonesian clearing house mechanism. This will be essential in monitoring the delivery of Aichi targets in Indonesia and will become a national resource for plant biodiversity research in Indonesia. Lastly, we were informed that the number of plant taxonomists in Indonesia has increased in the last three years from 69 to 77 and that 31 of these were based in Herbarium Bogoriense.

A very popular aspect of the 10th Flora Malesiana Symposium was the series of workshops that took place throughout the week. This would not have been possible without many people giving up their valuable time to host these events. I would particularly like to thank Toby Pennington and Subhani Ranasinghe of RBGE for the Interpreting and Presenting Phylogenetic Trees workshop; John McNeill, Chairman of the editorial committee of the International Code of Nomenclature for Algae, Fungi and Plants, for chairing the Nomenclature Helpdesk; Sadie Barber and Helen Yeats from RBGE and Wisnu Handoyo Ardi of Kebun Raya, Bogor for coordinating the Cultivation of Tropical Plants workshop; Katie Beckett of the Department for Business, Innovation and Skills for setting out the UK Government's approach to Implementing the Nagoya Protocol on Access and Benefit Sharing; Malin Rivers of Botanic Gardens Conservation International and Sara Oldfield of IUCN/SSC Global Tree Specialist Group for helping delegates navigate through the process of Submitting Global Red List Assessments to the IUCN Red List; and David Middleton of Singapore Botanic Gardens and Robyn Drinkwater of RBGE for giving their time to share their Taxonomy Tricks of the Trade. I would also like to thank Gail Scott, who, at short notice, was willing to make a record of the workshops.

I hope that, together with the symposium programme, the papers published here are a fair and useful record of the symposium and that the sense of commitment to researching 
and conserving the flora of the Malesian region, so noticeable at the symposium, will be conveyed to the reader.

Since the symposium, we have been very sad to learn of the passing of Jan Frits Veldkamp and Tony Whitten. Short obituaries for both of them are given in this volume but I think it particularly important to acknowledge the massive contribution of 'JeF' Veldkamp to the Flora Malesiana project and the Flora Malesiana community. His contributions are fittingly documented in detail in the most recent issue of Blumea.

On the last day of the symposium, it was heartening to hear that there has been an increase in the number of taxonomists employed in Indonesia. This is particularly welcome at a time when we hear of the older generation of taxonomists in Europe retiring and not being replaced. The popularity of the workshops at this symposium indicated that there is a need to provide help and advice to the new generation of taxonomists from the Malesian region. It is clear that Flora Malesiana has an important role to play here. It was also clear during the symposium that, although it is essential that we continue to focus our efforts on producing taxonomic accounts, we also need to strengthen our links to a wider range of stakeholders and, in particular, to the conservation community.

Finally, I would like to thank RBGE for supporting the symposium and the organising committee for all their hard work in delivering a successful event. Most of all, however, I would like to thank all the delegates for presenting a wide range of talks and posters over the week and for making the symposium such an interesting and inspiring one.

Dr Peter Wilkie

Chairman of the 10th Flora Malesiana Symposium

Royal Botanic Garden Edinburgh

16 March 2018 